\title{
FIRE SAFETY OF WASTE STORAGE
}

\author{
Anders Lönnermark ${ }^{1}$ \\ Henry Persson ${ }^{1}$ \\ Per Blomqvist ${ }^{1}$ \\ William Hogland ${ }^{2}$ \\ ${ }^{1}$ SP Technical Research Institute of Sweden \\ ${ }^{2}$ Linnaeus University
}

\begin{abstract}
The EC Directive on landfill of waste and the development of different national regulations, together with the need and interest for biofuels, have resulted in more extensive handling and storage of these products. Calorific value and bulk density are for most fractions lower than for example oil, which translates into a further increase in volumes of fuel needed for a given amount of energy. Since the material is to be used as a high-grade fuel, higher requirements are placed on the storage technology. There will also probably be strong desire to place stocks in direct connection with for example a specific industry or co-generation plant, to minimize the need for transport. Overall, this means that very large production and handling facilities with large stocks will be required. These new types of storages also mean new types of risks. There is therefore a great need for knowledge on the risks for spontaneous ignition, fire characteristics, and risk for fire spread for these fuels and storages. If a fire occurs it can lead to significant problems with emissions and in many cases the rescue services have problems with handling these fires. These fires can also lead to large economic losses. It is, therefore, important to know both how to avoid and how to facilitate extinguishment of these fires. In the paper some trends regarding storage of waste are discussed together with the risks for self-heating and emissions. Experiences from real fires are presented and some existing guidelines for storage of waste are discussed.
\end{abstract}

\section{KEYWORDS}

Storage; waste; fire safety; auto-ignition, self-heating; detection; fire spread; extinguishment; guidelines.

\section{INTRODUCTION}

Climate change and a greater awareness of the over exploitation of the earth's finite resources, have placed politicians, industry and the public under great pressure to move towards a resource-saving society that uses renewable energy and employs maximum resource recovery. This has already led to major changes in society and further changes are expected. 
The gradual shift from fossil fuels to different types of biofuels and waste fuels will lead to much more extensive handling and storage of these products. Calorific value and bulk density are for most fractions lower than for example oil, which translates into a further increase in volumes of fuel needed for a given amount of energy. Since the material is to be used as a high-grade fuel, higher requirements are placed on the storage technology. There will also probably be strong desire to place stocks in direct connection with for example a specific industry or co-generation plant, to minimize the need for transport. Overall, this means that very large production and handling facilities with large stocks will be required. Industry handling and storage are often focused on maximum efficiency.

Waste management also includes sorting, collection and reprocessing of waste in various custom-built facilities for later use as new raw material or fuel (energy). The reason for this complex chain from sorting to storage is the Landfill Directive (1999/31/EC) and national legislations which prohibits the deposition of household and other organic waste. Waste to be used for energy is normally stored outdoors. As the waste is produced relatively evenly all year round while the need for heat and energy is highest during the winter, very large stocks can accumulate. The storage must then be arranged so the energy and mass losses are as small as possible and the emissions to air and water limited.
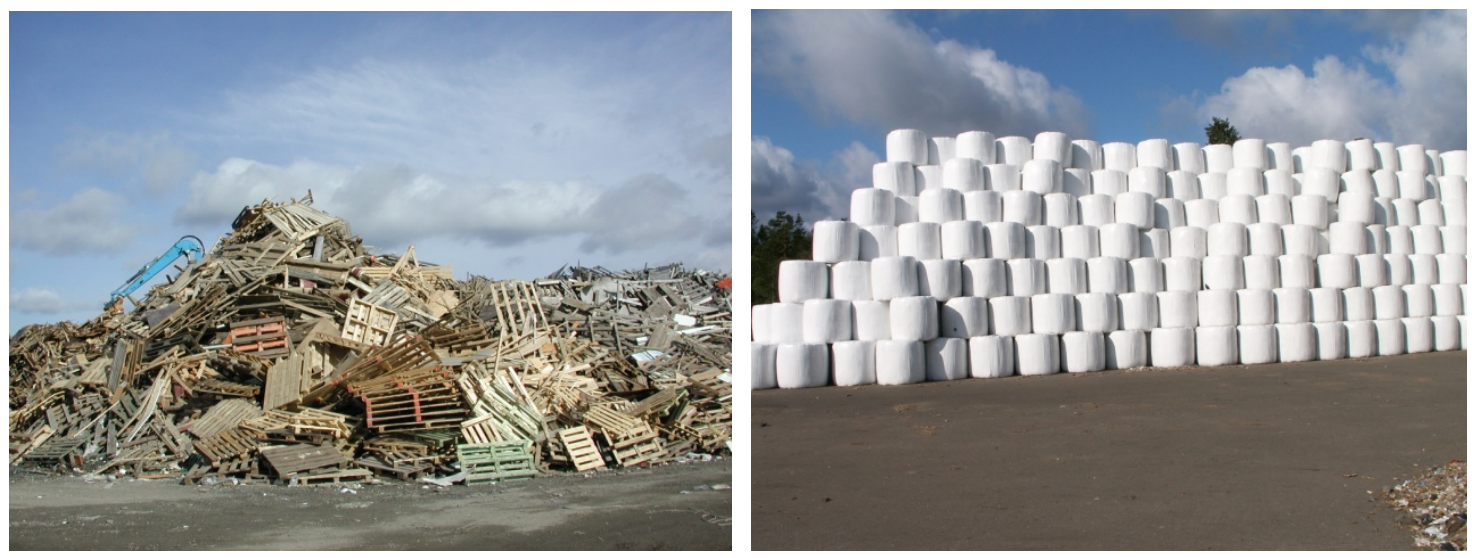

Figure 1. Non-compacted sorted waste (left) and baled household waste (right).

There are several different methods of storage. In a non-compacted storage, the waste is stored loosely in piles (see Figure 1), well ventilated by the wind. The waste is compacted only by the weight of the waste itself. To store large amounts of waste on a limited surface, compacted storage is used. In this type of storage $30-50 \mathrm{~cm}$ of waste is distributed in a layer, which is compacted before a new layer is distributed and compacted. There exist up to $10 \mathrm{~m}$ high compacted piles of this type. Waste can also be stored in bales, either round or rectangular. These are often also wrapped with plastics 
(see Figure 1). Some advantages with baling are small energy and mass losses, clean transport, and reduction of volume. If wrapped with plastic, it is a largely watertight storage and decreases the problems with odour compared to other types of storage. The bales are stored in several layers in large stacks. Other modes of storage that are used include the compaction and wrapping of long "loaves" of waste or the production of pelletized waste.

Perhaps the most common cause of fire in large bulk storages is spontaneous ignition. Self-heating depends on microbial activity, chemical oxidation and physical processes that can lead to spontaneous ignition after a few days, but more commonly after a few months or longer, depending on the circumstances. In the current situation, it is very difficult to distinguish between a normal temperature increase and a "dangerous" temperature increase that could lead to spontaneous combustion. Further, other causes of fire can occur in the form of various external sources of ignition (e.g., fire in a working vehicle, lightening, bush fires, arson, etc.), which also must be considered.

A fire often leads to major problems from emissions (smoke, odours, toxic gases, extinguishing run-off water) to the surroundings and makes great demands on the local rescue services, which in the current situation are not designed and equipped for this type of fire. Through increased knowledge, the rescue services will be given a fair chance to deal with these fires through education, acquisition of relevant equipment and applying the correct tactics. Another important aspect is the working environment during a fire fighting operation, e.g. in terms of exposure of fire fighters, plant workers, and other personnel to toxic emissions.

For plant owners, it is necessary to take appropriate risk mitigation measures already in the planning and construction of the plant so that the fires are avoided or limited as far as possible. The method of storage has a major impact on the risks and there are many issues that are important for the industry to find answers to: How large piles can you store of different materials without risk? What is the minimum safety distance between storage piles? Is flat storage safer than silo storage? Should piled storages of solid biofuels and waste be compacted or not? Are the risks reduced by sorting the waste material? How safe is the storage of baled material? What is the difference between different types of bales? and much more.

As solid biofuels and different fractions of waste are handled and stored in large quantities in various industrial establishments (e.g. biofuel producers, facilities for waste sorting and reprocessing, CHP, industry), there is a high risk that incipient fires in the fuel can rapidly spread in the plant and cause serious damage. Even a fire in the outdoor stocks can spread to adjacent buildings and structures. Again, knowledge of the ignition and fire development is needed to take the proper precautions

Finally, one cannot ignore the economic aspects of a fire in large fuel stocks. The direct costs of the destroyed fuel, damage to structures of the plant, etc. and the costs for emergency operations and cleaning up can be very extensive. These fires also generate a 
variety of indirect costs, which in many cases are not normally included in the total damage cost. This may include downtime costs, both in the affected plant and for surrounding buildings that must be closed because of fire gases, etc. Accommodation in adjacent residential areas may be affected and not least, there might be long-term costs because of pollution to air, land and water. In the case of a fire during the cold season, it can also affect third parties considerably through, e.g., the interruption of district heating.

The information in this paper is based on a report describing trends and state-of-the-art of knowledge on fires in storages of solid biofuel and waste [1]. The report also includes descriptions of research needs in the form of a suggested research programme. 


\section{FIRE RISKS RELATED TO WASTE STORAGE}

Storage in large piles is nothing new in itself, but storage of material for high-grade fuel leads to new requirements for the storage technology and also increases the storage volumes at local sites for temporary storage.

Perhaps the most common cause of fires in this type of bulk storage is the risk of spontaneous combustion. Biomass and waste is often porous, moist material, which can exhibit self-heating from microbial activity, chemical oxidation and physical processes such as transport and adsorption of water. The result of self-heating in stored materials is a balance between heat production in the bulk and the dissipation of heat from bulk surface (boundary layer). Therefore the risk of spontaneous combustion increases with a larger volume stored, since the heat losses decrease as the relative surface area decreases with increasing volume.

Self-heating can lead to spontaneous combustion after a few days, but more commonly after several months or longer, depending on the circumstances. Spontaneous combustion is an exothermic process (i.e,, generates heat), which requires the availability of biodegradable materials and the presence of oxygen. The phenomenon is generally described as a streaming / diffusion problem where the transport of moisture, heat and oxygen are the most important mechanisms.

In discussing self-heating of solid biofuels, one should distinguish between wet fuel and dry fuel (moisture content of up to about $10 \mathrm{wt} \%$ ), since especially the initial selfheating process differs.

Wet fuel, with a relatively high moisture content, include wood chips, bark, and certain types of waste. Wet waste is in many cases stored outdoors. Household waste is also increasingly baled. Microorganisms such as fungi and bacteria require a relatively high humidity to thrive ( $>20 \%$ by weight of material). Microorganisms are the initial source of heat for this kind of material, in some cases together with physical processes, such as water transport.

Microorganisms metabolism causes an increase in temperature of the stored fuel. Microbial activity contributes to the increase in temperature within the temperature range $0-75{ }^{\circ} \mathrm{C}$. The maximum temperature caused by microorganisms varies with the type of microorganism and depends on the specific biological material comfort temperature [2]. Chemical oxidation may contribute to the development of temperature already at $40{ }^{\circ} \mathrm{C}$ and the chemical processes begin to dominate in the temperature range $60-70{ }^{\circ} \mathrm{C}$. At temperatures above $90{ }^{\circ} \mathrm{C}$ the oxidation is controlled only by chemical processes. Oxidation processes require oxygen in order to continue. It has been shown that the oxidative degradation process is faster and therefore gives a greater heat in wood materials, which contain higher levels of lignin [2] and that the presence of metals increased oxidation [3]. The main factors affecting the temperature of a stack with a certain type of wood fuel are: the moisture content of the material, moisture gradient in the stack when piled up, stack size, and density of the material. The actual ignition can 
result in flaming combustion with visible flames in the case the pyrolysis spreads to the surface of the stack.

The greatest risk of spontaneous ignition of waste is found in stocks that are not compacted or poorly compacted [4]. The air will usually come in through the layers and sides of the pile or from the surface due to poor compaction or no compaction at all, creating zones with both aerobic and anaerobic conditions. Compaction due to the weight of waste and waste decomposition can create completely anaerobic zones.

Experience has shown that such household waste that is stored in piles self-compacts and should therefore not be stored higher than a maximum of $3 \mathrm{~m}$ to reduce the risk of "dangerous" self-heating. Hard compacted stocks of waste, which is an anaerobic type of stock, may be higher. Storage of up to 8-10 m height can occur, but in those cases the risk of fire is imminent. The temperature rise in such cases is usually very fast up to 70 ${ }^{\circ} \mathrm{C}$ or higher and spontaneous ignition usually occurs after one to eight months.

Surveys indicate that the baling of waste may be the safest storage principle as long as the storage area and storage height is not too great. The temperature in a bale with waste usually does not exceed $70{ }^{\circ} \mathrm{C}$ which is attributed to the relative humidity in bales (45$50 \%$ ). However, there are different methods of baling (round bales, square bales, wrapped, etc.) and its effect on the risk for spontaneous ignition is not yet fully understood. The same applies to the influence of the type of stored material.

In field studies in very large stores of baled household waste very high levels of methane gas have been measured, up to $50 \%$. In addition to that the high concentrations is a climate issue due to the strong greenhouse effect of methane, it is also a sign that there is a degradation process inside the layer. This is also likely to generate heat that in certain circumstances can lead to spontaneous combustion. The high methane concentrations are, of course, a direct fire hazard issue, since it means that there may be a combustible gas mixture inside the storage that can be ignited.

Spontaneous ignition of relatively dry waste derived fuel (paper, plastic, fabric) and other dry waste should be less frequent, but the risk cannot be ruled out completely, depending on the specific material content and in cases of a subset of moist material costored with a dry material.

Research is conducted in Japan on the risks for spontaneous ignition of stored waste, since there have been a number of serious fires in stock with pelletized waste [5]. The waste is listed as RDF, but is probably to some extent also household waste. Waste moisture content was relatively low (from $3 \mathrm{wt} \%$ and $27 \mathrm{wt} \%$ in tested samples [6]). The problems with self-heating were identified as initiated by wetting and moisture transport, in the case material is exposed to moisture, and by microbial activity [7-8].

\section{FIRE INCIDENTS IN WASTE STORAGE}


In the case of fires in piles of waste and landfills more than 200 fire incidents were reported in Sweden annually in the 1990s corresponding to an estimated volume of 25 000 tonnes [4]. The Swedish Waste Management Association collects incident data as well which has been published occasionally [9]. This data shows that in e.g. year 2002, 69 fires in landfills in Sweden were reported. The incident survey also shows that fires in different types of "stored fractions" dominate (4097 tonnes). The most frequent fire incidents occurs in mixed household waste (total about 325 tonnes) while the largest mass consumption by fires is related to wood, paper and plastic (2658 tonnes). One conclusion from this is that the risk for fires is not reduced when dealing with sorted fractions, instead it might be the opposite. There is no statistics available indicating a clear reason for this, perhaps it could be a result of larger storages in combination with longer periods of storage.

To give an idea of the various types of fire incidents that may occur, below is included a brief summary of some fires that occurred in recent years in various types of waste storages and waste recycling plants.

During 2006 there was a fire in an intermediate storage of combustible waste on two occasions (Aug and Sept) in Södertälje (Sweden). The storage contained about 1600018000 tonnes of waste and consisted of a stack of about $200 \mathrm{~m}$ long, $70 \mathrm{~m}$ wide and about $60-10 \mathrm{~m}$ high. The cause of the fire was probably spontaneous ignition. The primary tactics was to split the stack by excavating to create a fire break and to allow the material in the affected part of the stack to burn out. However, after a week, smoke emissions to the neighbourhood forced the fire brigade to change tactics to a more active fighting operation by excavating the burning material and more or less drown it in water. After about 4 weeks, the unaffected part of the stack ignited. This time, an offensive fire fighting operation was started immediately by excavating the material and flood it in water. This time, the stack was also covered with foam which reduced the smoke emissions significantly. The excavation and extinguishing operation lasted for almost a week to ensure that no hotspots remained. However, the extinguishing operation created many problems with very large amounts of contaminated run-off water and large amount of very wet material with a reduced market value. A total of about $17000 \mathrm{~m}^{3}$ of water and $4400 \mathrm{~L}$ of fire fighting foam concentrate was used. The wet material was also considered to increase the risk of subsequent spontaneous ignition. During the fire fighting operation, there was also obvious risks of accidents due to the combination of smoke and the fact that machines and operational personnel were forced to work in parallel [10-11].

In October 2005, a major fire occurred in a storage of baled materials in Aalborg (Denmark). Overall, about 12000 tonnes of waste was stored on the $8000 \mathrm{~m}^{2}$ area when the fire started. The bales were stacked four pcs in height, corresponding to a storage height of 4-5 m. The original fire started in some adjacent loosely stored material but spread very quickly to the stack of bales. Although the fire brigade was quickly on site, there was no chance of getting the fire under control. When the stack was fully involved in fire, the flame height was estimated to about 30-40 m with occasional sparks reaching 
about $70 \mathrm{~m}$. After about two hours, a decision was taken to allow the layer to burn out, as the thermal radiation was very high and the fire fighting resources were not sufficient. Instead, the operation focused on preventing fire spread to nearby buildings and surroundings. However, after three days a wind shift turned the smoke plume towards Aalborg city and a decision was taken therefore to try to extinguish the fire. This was achieved by covering the stack with about $10000 \mathrm{~m}^{3}$ of a mixture of wet clay, chalk and soil using a large number of dumpers, excavators and bulldozers. This took more than 24 hours of intense work and smoke was visible for more than 2-3 weeks after the coverage [12-13].

In June 2008, a fire occurred in a landfill in Huddinge (Sweden). The landfill was used for sorted waste, which according to the waste directive may contain a maximum of $10 \%$ organic material. The landfill had an area of approximately $350 \mathrm{~m}$ by $150 \mathrm{~m}$ and a depth of up to about $20 \mathrm{~m}$. A CAFS equipment (Compressed Air Foam System) was used to control the fire and reduce the production of smoke. Final extinction was carried out by covering the entire landfill area with a layer of slag.

In May 2008, a 6,000 $\mathrm{m}^{2}$ warehouse for storage of recycled plastic and paper was destroyed in a fire close to Ulm (Germany). Nearly 300 fire fighters took part in the fire fighting operation, which was further complicated by insufficient capacity of the fire hydrants. Instead, water had to be pumped to the site in hoses from the river Danube. All fire fighting waste water was collected in a rainwater reservoir and reused in an attempt to reduce the total amount of contaminated runoff from fire. Fire fighting took more than 24 hours and the damage was estimated to $€ 10$ million [14].

In June 2007, a fire occurred in an electronics recycling company in Norrköping (Sweden). The fire probably started in a large pile of defragmented scrap from electronics gadgets, (computers, circuit boards, plastic hardware, etc.). The fire occurred inside an industrial building but after a while it spread to a pile and a stack of bales on the back yard. The fire produced a lot of smoke and about 20 fire fighters were involved in the fire fighting operation. Approximately $3,000 \mathrm{~m}^{3}$ of water and $200 \mathrm{~L}$ of foam concentrate were used.

In July 2001, a stack of batteries was involved in a fire at a battery recycling company in Landskrona (Sweden). The stack contained about 14000 tonnes of scrap batteries. Toxic smoke spread in the wind direction and reached a residential area about one kilometre away. Initially, large amounts of water were used for the fire fighting operation but without success. After about $1 \frac{1}{2}$ days, the tactics was changed and the stack of batteries was covered with a layer of sand [15].

In September 2001, a fire occurred at a rubber recycling company in Malmo (Sweden) which involved about 6000 tonnes rubber waste. The cause of the fire was probably friction from foreign objects in a mill and the fire then spread to a stack of scrap tires. 
Various extinguishing methods were considered and regarding also the environmental impact, it was decided to dump the burning tires in the basin. The operation was completed about three days after fire outbreak [16].

In October 2007, a $46000 \mathrm{~m}^{3}$ large stack of metal scrap was involved in a fire at a shredding and recycling plant in Herbertingen (Germany). The fire occurred inside the stack and was detected as a small smoke plume from the surface. The fire was then was growing faster than the fire brigade could mobilize sufficient equipment and personnel resulting in a fire involving the entire stack. After an extensive extinguishing operation with foam it was possible to control the fire. The fire lasted for a total of five days and involved in total 700 men, 184 vehicles and a total work effort of more than 20000 man-hours. More than $120000 \mathrm{~L}$ of foam concentrate was consumed and a number of fire and police vehicles were destroyed [17-18].

\section{GUIDELINES}

Today there exist very few guidelines related to storage of biofuels and industrial waste. Most of them are related to outdoor storage of wet biofuels (wood chipes, etc). When it comes to waste, there are several directives and regulations that are relevant, e.g., the Landfill Directive [19], which deals with what can and cannot be deposited. However, to a large extent, clear guidelines on how the waste should be stored are not available. One exception is some guidelines on the storage of scrap tires, published by MSB Swedish Civil Contingencies Agency in 1996 [20].

On behalf of the Swedish Waste Management Association the consultant company Öresunds Safety Advisors AB has developed a guide for fire risk analysis in landfills [21]. The aim is to provide guidelines on how a fire risk analysis for waste storages can be performed and what it should contain. Based on the type of stored waste and the location in relation to its surroundings, the plant owner can find suggestions for appropriate design of the storage.

However, an analysis of the methods indicates a lack of knowledge on several key areas to conduct risk assessments based on scientific results. There is, therefore, a great need to fill these knowledge gaps by experimental fire test data from various types of waste materials.

As early as 2003, the Swedish Waste Management Association, published some recommendations for landfills and incinerators [9]. The purpose of this publication was to make proposals for actions and discussion on how management of waste can be improved to avoid fire situations. The investigation was a follow-up of a similar survey conducted ten years earlier. The report focuses on landfill fires and contains statistics on fires occurred, type, size, cause, etc.

\section{CONCLUSIONS}

The study presented in the paper demonstrates the major shift that has begun to replace fossil fuels with different types of bioenergy. To achieve this will require many 
different energy options and technologies. The amounts of waste and solid biofuels are increasing. This has led to increased sizes and new types of storages. Frequent fire incidents show the need for more knowledge and guidance on how to store waste and solid biofuel safely.

A fundamental problem is the lack of "risk parameters" for the new biofuels and waste, equivalent to those available for traditional fuels in liquid and gaseous form (flash point, auto-ignition point, etc.). Such risk parameters could be used to characterize the stored material and give information on risks for spontaneous ignition and subsequent fire spread. Based on this, guidelines for storage can be developed. This can include type (silo storage, flat storage, compactation, bales, etc.) and size of storage and safety distances between different piles.

Furthermore, the rescue services often lack methods and training for fires in large storages of waste and solid biofuels. There are many examples from real fire incidents showing that fire extinction is a major problem. More knowledge is needed to help both plant owners and emergency services to deal with a fire situation. Future work should involve development of new fire fighting tactics with the goal of both reducing the direct damage, maintaining high fuel quality of the material not been directly exposed to the fire and minimizing the impact on humans and the environment. The need for early detection should also be considered.

Large consequences of the fires with economical losses and effects on the environment emphasize the need for knowledge regarding storage risks and risk mitigation, firefighting tactics and mitigation of consequences of fires in storages of waste and solid biofuel.

\section{ACKNOWLEDGEMENT}

This paper is based on work financed by The Swedish Fire Research Board and this is gratefully acknowledged.

\section{REFERENCES}

1. Lönnermark, A., Persson, H., Blomqvist, P., and Hogland, W., "Biobränslen och avfall - Brandsäkerhet i samband med lagring", SP Sveriges Tekniska Forskningsinstitut, SP Rapport 2008:51, Borås, 2008.

2. Kubler, H., "Heat Generating Processes as Cause of Spontaneous Ignition in Forest Products", Forest Products Abstracts, 10, 11, 299-327, 1987.

3. Wadsö, L., "Measuring chemical heat production rates of biofuels by isothermal calorimetry for hazardous evaluation modelling", Fire and Materials, 31, 241$255,2007$. 
4. Hogland, W., "Säker laging av avfallsbränslen genom utnyttjande av balningsteknik", DAKOFA konference om stop for deponering - af forbraendningsegnet affald, Köpenhamn, Danmark, 1 September, 1997.

5. Gao, L., and Hirano, T., "Process of accidental explosions at a refuse derived fuel storage ", Journal of Loss Prevention in the Process Industries, 19, 2-3, 288-291, 2006.

6. Gao, L., Tsuruda, T., Suzuki, T., Ogawa, Y., Liao, C., and Saso, Y., "Possibility of Refuse Derived Fuel Fire Inception by Spontaneous Ignition", 6th AsiaOceania Symposium on Fire Science and Technology, 102-107, Daegu, Korea, 2004.

7. Fu, Z.-M., Li, X.-R., and Koseki, H., "Heat generation of refuse derived fuel with water", Journal of Loss Prevention in the process industries, 18, 27-33, 2005.

8. Fu, Z.-M., Koseki, H., and Iwata, Y., "Investigation of spontaneous ignition of two kinds of organic material with water", Thermochimica Acta, 440, 68-74, 2006.

9. RVF, "Bränder i avfall vid deponier och förbränningsanläggningar", Svenska Renhållnigsverksföreningen, RVF rapport 2003:11, Malmö, Sweden, 2003.

10. Hogland, W., "UItlåtande kring branden vid Telge Återvinning", Högskolan i Kalmar, 2007.

11. Hogland, W., Marques, M., and Björklund, B., "Fires in Organic Waste Storages: Prevention, Fire Fighting and After Care", Eco-Tech '07, 3-10, Kalmar, Sweden, 26-28 November, 2007.

12. Hogland, W., Nammari, D., Sandstedt, K., and Stenis, J., "Brand i lagrat avfallsbränsle hos Cemmiljö A/S i Ålborg", RVF - Svenska Renhållningsverksföreningen, RVF:s Utvecklingssatsning Deponering, Rapport nr 6, Malmö, 2006.

13. Hogland, W., Nammari, D., Sandstedt, K., and Stenis, J., "Det brinner! Branden i CemMiljös avfallslager i Ålborg", In RVF-Nytt, 2006.

14. "Fire Destroys German Recycling Plant", European Fire Sprinkler Netwoek, http://www.eurosprinkler.org/full article.asp?bucket01=368, 2008.

15. SRV, "Brand i batterilager, Boliden Bergsöe, Landskrona 2001-07-13 Insatstillsyn och utvärdering", Räddningsverket, R00-251/02, 2002.

16. Krook, M., "Svårsläckt brand när 6000 ton gummi stod i lågor - Skadekostnaden slutade på 60 miljoner kronor", In Brand \& Räddning, 2002. 
17. Hack, M., and Baumhauer, R., "Herbertingen: Großbrand einer Schrotthalde", In Deutsche Feuerwehr-Zeitung BrandSchuttz, 2008.

18. Hack, M., and Baumhauer, R., "Grossbrand einer Schrotthalde in Herbertingen: Schumangriff über mehr als 15 Werfer", In Magazin, 2008.

19. "Rådets Direktiv 1999/31/EG av den 26 april 1999 om deponering av avfall", In Europeiska gemenskapernas officiella tidning, 1999.

20. "Storskalig utomhuslagring av gamla bildäck", In Aktuellt/SRV, 1996-11, 1996.

21. Avfall Sverige, "Att minska risken för brand på deponier - Förslag till brandriskanalys", Avfall Sverige - utveckling, Rapport D2007:05, Malmö, 2007. 